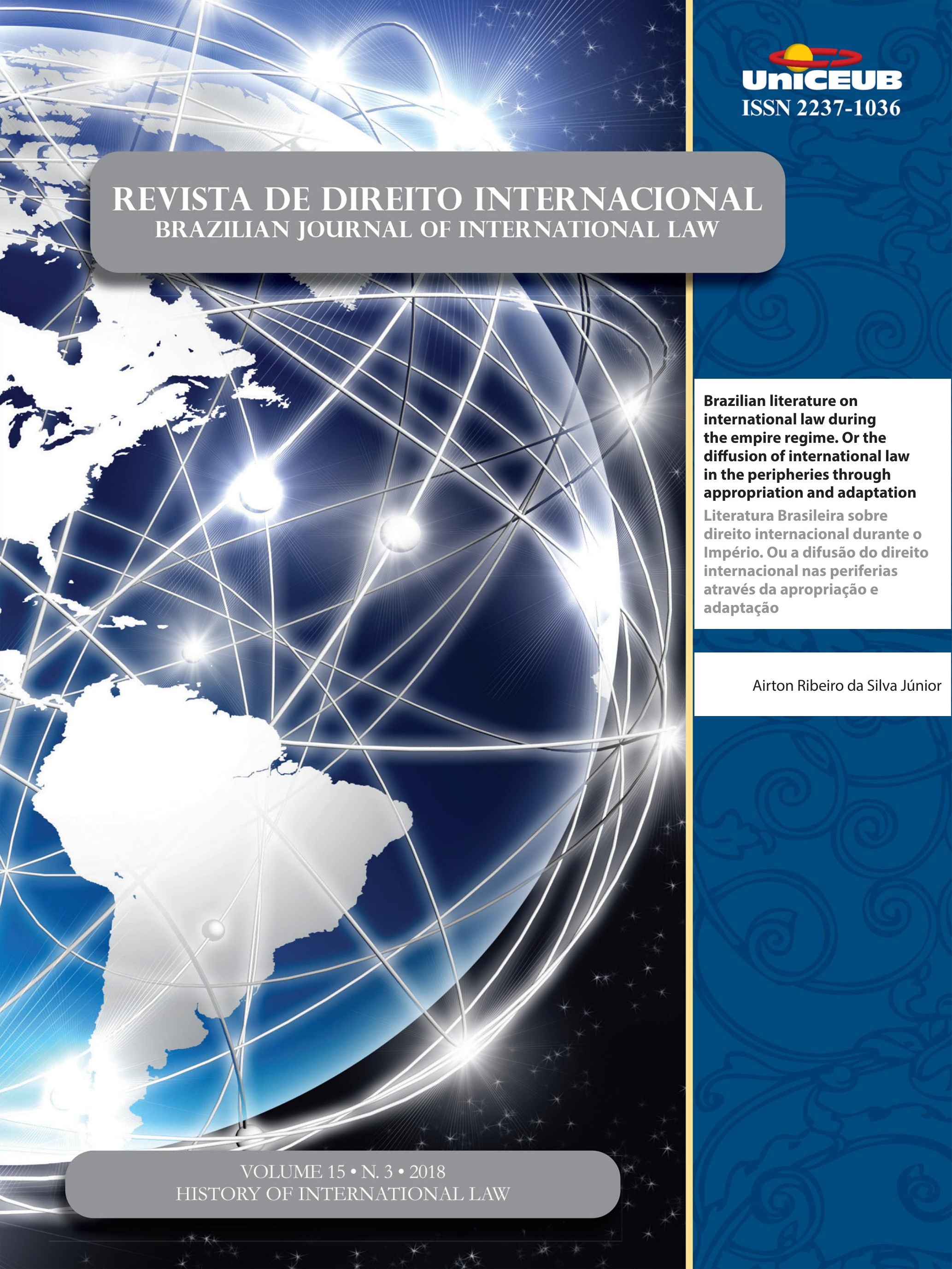




\section{Sumário}

I. Dossiê Especial: History of International Law ...................................1

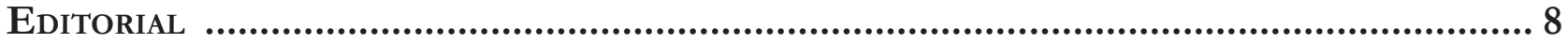

What does it mean to apply history in international law studies? ....................................................... 8

Arthur Roberto Capella Giannattasio

SuR LA NATURE DU Droit ISLAMIQUe............................................................................14

Hocine Benkheira

Islamic Shari’a Law, History and Modernity: Some Reflections .................................25 Suleiman A. Mourad

The (Un)practical Secularization Process: International Law and Religion as So-

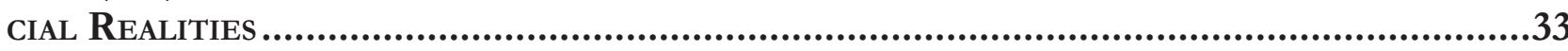

Douglas de Castro

BRAZILIAN LITERATURE ON INTERNATIONAL LAW DURING THE EMPIRE REGIME. OR THE DIFFUSION OF INTERNATIONAL LAW IN THE PERIPHERIES THROUGH APPROPRIATION AND ADAPTATION.

Airton Ribeiro da Silva Júnior

Natural, POSitivo, romano E Universal? INVESTigaÇão SObre O Direito das GENTES EM

Tomás de Aquino

Rafael Zelesco Barretto

II. Artigos sobre outros temas

VINCULAÇÃO DOS DIREITOS ECONÔMICOS, SOCIAIS E CULTURAIS: UMA DISCUSSÃO DO DESENVOLVImento humano com base no conceito de Amartya Sen sobre o mínimo existencial.....99

Natalia Mascarenhas Simões Bentes e Yasmim Salgado Santa Brígida

A NOVA LeI de MigraÇão E A PROTEÇão CONFERIDA AO APÁtrida: ALINHAMENTO BRASILEIRO AO PADRÃO INTERNACIONAL DE DIREITOS HUMANOS

Pedro Henrique de Faria Barbosa e Sylvio Loreto

E se o Supremo Tribunal Federal (STF) restabelecer a vigência da Convenção n. 158 
da Organização Internacional do Trabalho (OIT) na ordem Jurídica brasileira? SoBRE UMA POSSÍVEL REVIRAVOLTA, PELA VIA DO DIREITO INTERNACIONAL, DAS LEIS TRABALHISTAS BRASILEIRAS 138

Daniel Damasio Borges

JULGADOS DA CORTE INTERAMERICANA SOBRE CASOS BRASILEIROS E POLÍTICAS PÚBLICAS: REFLEXÕES ACERCA DE POSSÍVEIS INFLUIÇÕES 165

Rafael Osvaldo Machado Moura

CREATING BRIDGES BETWEEN INTERNATIONAL RELATIONS THEORY AND INTERNATIONAL HUMAN RIGHTS LAW: CONSTRUCTIVISM AND THE ROLE OF BRAZIL IN THE INTER-AMERICAN SYSTEM OF HUMAN RIGHTS 179

Ismael Francisco de Souza, Luciana Rocha Leme e Erick da Luz Scherf

Justiça de transição na Argentina e o Sistema Interamericano de Direitos Humanos: uMa ANÁlise do CASo Luis Muiña (“REgRa 2x1”) 199

Emilio Peluso Neder Meyer e Jessica Holl

A legalidade e legitimidade da INTERVEnÇão humanitÁria: UMA MEDIDA AINDA NECESSÁRIa.219 Natália Caye Batalha Boeira

O Acordo de Escazú E o ACESSo À INFORMaÇão AMbiental no Brasil. 252 Érica Bezerra Queiroz Ribeiro e Bruno Amaral Machado

Dos POVOS NATIVOS AO SURGIMENTO DOS MOVIMENTOS SOCIAIS: INFLUÊNCIAS DOS DISCURSOS JURÍDICOS, RELIGIOSOS E MÉDICOS PARA A CONSTRUÇÃO DO CONCEITO DE HOMOSSEXUALIDADE NO BRASIL .267 Bruno Rafael Silva Nogueira Barbosa e Robson Antão de Medeiros

Aspectos Jurídicos da PARTicipaÇão dA UNião Europeia NA OMC: COMPREENDENdo SUTILEZAS DE UM DELICADO ENLACE. 291

Camilla Capucio

Path to judicial activism? The use of "Relevant rules of international law" by the WTO Appellate Body

Mariana Clara de Andrade

LEVEZA E PESO NA MEDIAÇÃO COMERCIAL INTERNACIONAL: O CONTEÚDO JURÍDICO DO ACORDO CORPORATIVO MEDIADO E SUA INCORPORAÇÃo PELO DiREITO BRASILEIRO .324 Henrique Lenon Farias Guedes 
JURISDIÇÃO INTERNACIONAL E AS DIFICULDADES DE EXECUÇÃO DE SENTENÇAS INTERNACIONAIS NO BRASIL

Nevitton Vieira Souza

O DEVER DE COOPERAÇÃo NOS CONTRATOS DE VENDA INTERNACIONAL DE MERCADORIAS: PRESSUPOSTOS TEÓRICOS E REPERCUSSÕES PRÁTICAS DA CLÁUSULA GERAL DA BOA-FÉ OBJETIVA PARA A APLICAÇÃo DA CISG .358

Angelo Gamba Prata de Carvalho

A DiMENSÃo JURÍdiCA DO IMPERIALISMO NA (DES)ORDEM GLOBAL CAPITALISTA: UMA ANÁLISE COM BASE NA CRÍTICA MARXISTA AO DIREITO INTERNACIONAL E ÀS RELAÇÕES POLÍTICO-ECONÔMICAS DE DOMINAÇÃO E DEPENDÊNCIA.

Thomaz Delgado De David, Maria Beatriz Oliveira da Silva e Rosane Beatris Mariano da Rocha Barcellos Terra

A participaÇão de Brasil e Estados Unidos na formulação das regras multilaterais do

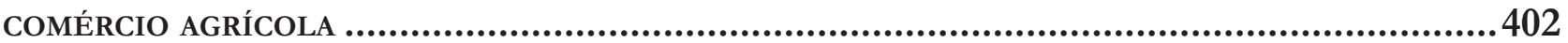

Vera Thorstensen, Vivian Daniele Rocha Gabriel e Alebe Linhares Mesquita

A galáxia lex e a construÇão de um Sistema jurídico transnacional ........................ 441

Eugênia Cristina Nilsen Ribeiro Barza e Jéssyka Maria Nunes Galvão

Has the Ability of Truth Commissions to Recommend Amnesty Been Effective in Enhancing Perpetrator Cooperation? 453 Jeremy Sarkin

A CONCEPTUAL PAPER ON THE POLICY-FRAMEWORK THAT MIRRORS THE DYNAMIC LINK BETWEEN Human Security, Social Protection and Safety Nets, and Food and Nutritional Security: The Case of the "Gulayan sa Paaralan Program", the Philippines.... 478 Renato Lagapa Base

INCENTIVISING SMALLHOLDER FARMER LIVELIHOODS AND CONSTRUCTING FOOD SECURITY THROUGH HOME-GROWN SCHOOL FEEDING: EVIDENCE FROM NORTHERN GHANA .491

Clement Mensah

Policy COHERENCE In THE IMPLEMENTATION OF THE 2030 AgENDA FOR SUSTAINABLE DEVELOpment: the Brazilian School Feeding Programme Case Study .506 Mariana Werlang Girardi 


\title{
Brazilian literature on international law during the empire regime. Or the diffusion of international law in the peripheries through appropriation and adaptation*
}

\author{
Literatura Brasileira sobre direito \\ internacional durante o Império. Ou \\ a difusão do direito internacional nas \\ periferias através da apropriação e \\ adaptação
}

Airton Ribeiro da Silva Júnior**

\begin{abstract}
This essay attempts to understand the profile of Brazilian textbooks on international law published during the Brazilian Empire (1822-1889), in order to comprehend which doctrines and influences can be traceable in the Brazilian legal literature. In this sense, the article focused on the entanglements between Western and Brazilian knowledge, privileging the conception of moderation between cultures rather than unilateral imposition or reproduction - interpretations that eventually prevails on the study of diffusion of knowledge in legal history. The research revealed that all of the three textbooks that had been published during the Imperial political regime (1851, 1867, 1889) shared, in general, the same characteristics: all of them had been written by professors of the Faculty of Recife, they were all prepared to serve as textbooks to the discipline of international law, and the three books followed the Droit des Gens Moderne de l'Europe written by the German jurist Johann Ludwig Klüber. In fact, the very first book of international law published in Brazil, written by Pedro Autran da Matta Albuquerque, is an abridged translation of Klüber's book. The history of the discipline and the bibliography of international law in nineteenth-century Brazil had been neglected; the present essay modestly attempts to fulfil this gap narrating the diffusion of international law from an extra-European standpoint.
\end{abstract}

Keywords: legal history - international law - Brazilian legal literature - Brazilian Empire - plagiarism

Recebido em: 20/09/2018

Aprovado em: 11/02/2019

** Doutor em Teoria e História do Direito pela Università degli studi di Fïrenze. Mestre em Direito e Relações Internacionais pela Universidade Federal de Santa Catarina. Professor da Faculdade Paraíso do Ceará. Coordenador do Iure populum - Grupo de pesquisa em História da Cultura Jurídica CNPq/FAP-CE. E-mail: ribeiro.airton@hotmail.com

\section{Resumo}

O presente ensaio pretende entender o perfil dos livros brasileiros sobre direito internacional publicados durante o período do Império (1822-1889), a fim de compreender quais doutrinas e influências podem ser traçáveis na literatura jurídica brasileira. Nesse sentido, o artigo foca nos enredamentos entre o conhecimento brasileiro e o ocidental, privilegiando o conceito de 
moderação entre culturas ao invés da imposição unilateral ou mera reprodução - interpretações que eventualmente prevalecem no estudo da difusão do conhecimento na história do direito. A pesquisa revelou que os três livros-texto que foram publicados durante o regime político do Império $(1851,1867,1889)$ compartilham as mesmas características: todos os três foram escritos por professores da Faculdade de Direito do Recife, todos foram preparados para servir no ensino da disciplina de direito internacional, e todos seguem o livro Droit des Gens Moderne de l'Europe escrito pelo jurista alemão Johann Ludwig Klüber. $\mathrm{Na}$ verdade, o primeiro livro de direito internacional publicado no Brasil, escrito por Pedro Autran da Matta Albuquerque, é uma tradução abreviada do livro de Klüber. A história da disciplina e a bibliografia do direito internacional no Brasil do século dezenove tem sido negligenciada; o presente ensaio procura modestamente preencher esse hiato, narrando a difusão do direito internacional a partir de uma perspectiva não europeia.

Palavras-chave: história do direito - direito internacional - literatura jurídica brasileira - Brasil-Império plágio

\section{INTRODUCTION}

The essay attempts to understand the profile of Brazilian legal literature on international law published during the Monarchy, focusing particularly on the textbooks written by Brazilian jurists that appeared between 1822 and 1889. The problem raised by this research can be summed up in the following questions: what was taught through the textbooks of international law published during the Imperial Regime in Brazil (18221889), and which was the doctrine of international law and influences predominant in those books? Since the international law was not a branch of domestic law, but an exogenous body of norms formed hitherto without the participation of Brazil, the legal doctrine produced in Brazil probably would resemble a Western one. The idea, therefore, was to comprehend the traceable influences - even if it is a notoriously vague notion, and possibly problematic - in those textbooks.

The only three textbooks published in Brazil and written by Brazilians ${ }^{1}$ in that time were: Elementos do Direito das Gentes (1851) ${ }^{2}$ by Pedro Autran da Matta Albuquerque (1805-1881), Prelęôes de Direito Internacional $(1867)^{3}$ by Antônio Menezes Vasconcelos de Drummond (1794-1865) and finally, Lições de Direito das Gentes (1889) ${ }^{4}$ by João Silveira de Souza (1824-1906). The scene of that period was dominated by the professors of the Faculty of Recife, whose intention was to provide materials to serve in the teaching of international law. Those books - attached more to the eloquent paradigm ${ }^{5}$ - were characterised by a direct and synthetic register, with few references.

As a matter of fact, those three first books written in Brazil, concerning the international law, were deliberately and explicitly prepared for education purposes, as its prefaces made it clear. These books were usually short, and the explanations summarised, serving only as a general introduction to the discipline. As it will be explained, all of the three textbooks that had been published during the Imperial political regime (1851, 1867, 1889) shared, in general, the same characteristics: all of them had been written by professors of the Faculty of Recife, they were all prepared to serve as textbooks to the discipline of international law, and the three books followed the Droit des Gens Moderne de l'Europe written

1 There was also the four-volume collection of treaties celebrated by Brazil, gathered by the Director of the Brazilian Empire Archive, PINTO, Antonio Pereira, Apontamentos para o Direito Internacional, Rio de Janeiro: F. L. Pinto \& Cia, 1864. Nevertheless, it was a compilation of treaties, not a textbook.

2 ALBUQUERQUE, Pedro Autran da Matta, Elementos do Direito das Gentes, Recife: Typographia União, 1851.

3 DRUMMOND, Antônio de Vasconcellos Menezes de, Preleções de Direito Internacional, Recife: Typographia do Correio do Recife, 1867.

4 SOUZA, João Silveira de, Lições Elementares de Direito das Gentes, Recife: Typographia Economica, 1889.

5 The eloquent-forensic paradigm had been in force during the nineteenth century as a cultural framework that oriented and constrained the practices and ideas of the jurists at large. The archetype of jurist within this paradigm was the practical jurist, who privileged the spoken word over the written. Educated and skilled in giving eloquent speeches, the jurist, a lettered man, monopolized the pulpit at different instances, either in the tribunal, in the parliament or the classroom. Cf. PETIT, Carlos, Discurso sobre el discurso. Oralidad y escritura en la cultura jurídica de la España liberal, Madrid: Universidad Carlos III de Madrid, 2014; BENEDUCE, Pasquale, Il corpo eloquente. Identificazione del giurista nell'Italia liberale, Bologna: il Mulino, 1996. The importance of orality and eloquence in Brazilian culture, as a whole, had been stressed by many historians, such as HOLANDA, Sérgio Buarque de, Raízes Do Brasil, São Paulo: Companhia das Letras, 1995, p. 83; CARVALHO, José Murilo De, História intelectual no Brasil: a retórica como chave de leitura, Topoi, v. 2, n. 1, p. 123-152, 2000, p. 123-152. 
by the German jurist Johann Ludwig Klüber. The similarities between those three books, actually, justifies the periodisation elected here - the Brazilian Empire (18221889) -, since this group of books will differ from those that appeared later in the end of nineteenth century.

The essay is concerned with the possible entanglements between Western and Brazilian knowledge. On the whole, the diffusion of international law is conceived as an imposition from the West to the rest, or a simple and passive reproduction by the peripheries. However, this conception tends to disregard the unavoidable interactions that happen in that process, which hardly is a pure one-way transfer or a mere and full reproduction. Therefore, this article is sensible to the intricated relations, and as consequence, tends to emphasize the mediation promoted by the Brazilian jurists between the European doctrine and the Brazilian context. If peripherical jurists assimilated European legal models, then the task of the legal historian is to understand how this appropriation has taken place $^{6}$, how those exogenous theories were adapted, manipulated, arranged or instrumentalised according to their political interests.

The constant resort to the Western legal culture including here the United States -, as the archetype of a legal system, to be followed and appropriated, or simply serve as an authoritative source, resulted in being a general characteristic of the Latin American legal culture. It follows what Sally Merry Eagle sustained: "culture is the product of historical influences rather than evolutionary change, [...] marked by bybridity and creolisation rather than uniformity and consistency.". ${ }^{7}$ Consequently, a legal culture is inevitably a coalescence of different understandings and practices of law arranged and juxtaposed. This is the case especially in a peripherical context, where a paradox emerged immediately after the act of Independence: in a nationalist tone, the project of nation-building to forge a - never existing before national identity, pushed them away from the metropolitan culture; notwithstanding the Western culture never ceased to be the parameter and reference. This paradox is destined to influence the practices and production of

6 Cf., an example of it: SAMPAIO DE MORAES GODOY, Arnaldo, The reception of European ideas in Latin America: the issue of the German sources in Tobias Barreto, a prominent nineteenth century Brazilian legal scholar, Revista de Direito Internacional, v. 13, n. 1, p. 399-404, 2016.

7 MERRY, Sally, What is Legal Culture? An anthropological Perspective, Journal of Comparative Law, v. 5, n. 2, p. 40-58, 2012, p. 42. legal doctrine throughout the nineteen-century.

Few narratives have been written regarding the emergence of the discipline inside newly independent states from a non-Eurocentric perspective, this is, an account of the international law seen from an extra-European standpoint. ${ }^{8}$ As remembered by Arnulf Becker Lorca, "[...] the ignorance of our non-Western past is not accidental.". ' After all, for the conventional history of the discipline, the expansion of international law until universalization has been conceived as a unilateral and imposed process, where postcolonial states had only a submissively role: to adhere to an established set of rules in toto. Under these circumstances, the centrality of Western contexts of practice is always overemphasized, whereas it minimises the practices of international law outside the West. ${ }^{10}$

Accounting these systematic bias and suppressions that international law's history has been presenting, there is a severe demand to refresh this hegemonic, self-legitimising and celebratory version of the international law's past. Hence, there is a need for divergent narratives capable of defying the centrality of Western point of view and that reveal the ethnocentric character of a supposedly universal tradition. Nevertheless, it is not a matter of reviewing those mainstream narratives with a proper historical method, but of privileging histories that have been intentionally set aside of the disciplinary canon, in order to provide a more complex - and not so 'pure' and self-confident - panorama of international law's past. ${ }^{11}$ In essence, the task consists in moving from a bistory to bistories of international law. ${ }^{12}$

8 LORCA, Arnulf Becker, Mestizo International Law. A Global Intellectual History 1842-1933, Cambridge: Cambridge University Press, 2014, p. 9-24.

9 Ibid., p. 16.

10 LORCA, Arnulf Becker, Eurocentrism in the history of international law, in: PETERS, Anne; FASSBENDER, Bardo (Orgs.), The Oxford Hadbookf of the History of International Law, Oxford: Oxford University Press, 2012, p. 1035.

11 GALINDO, George Rodrigo Bandeira, Para que serve a história do direito internacional?, Revista de Direito Internacional, v. 12, n. 1, p. 339-354, 2015, p. 343-344.

12 In the same sense, Galindo argued: "O historiador crítico do direito internacional também possui importante função ética de apresentar o passado não como ele naturalmente é, mas como o bistoriador o vê.27 Trata-se de compromisso com o pluralismo de valores e o pluralismo de narrativas. Não bá interpretações infaliveis on indiscutiveis. O passado pode (e deve) ser visto de maneiras diferentes." GALINDO, George Rodrigo Bandeira, Para que serve a história do direito internacional?, Revista de Direito Internacional, v. 12 , n. 1 , p. 349. 
Since the so-called turn to history ${ }^{13}$ - associated with a postcolonial turn ${ }^{14}$ - within contemporary international law scholarship, more narratives aware of the Eurocentrism of the discipline have been written, denouncing how particularistic are some supposedly universal categories of international law. However, even if those narratives dealt with this problem and intended to overcome it, they discussed only Western themes ${ }^{15}$ - events, doctrines, or authors, all European. ${ }^{16}$ Thus, despite not being necessarily Eurocentric, they still are parochial. Indeed, few historical narratives have been written taking non-European sources as an object of research and assuming a point of view from outside Europe, especially when regards to Latin American practices of international law; ${ }^{17}$ and it is precisely this hiatus in inter-

13 GALINDO, George Rodrigo Bandeira, Martti Koskenniemi and the historiographical turn in international law, European Journal of International Law, v. 16, n. 3, p. 539-559, 2005.

14 Represented by the new trend in international law called Third World Approaches to International Law. Cf. OKAFOR, Obiora Chinedu, Critical Third World Approaches to International Law (TWAIL): Theory, Methodology, or Both?, International Community Law Review, v. 10, n. 4, p. 371-378, 2008; ANGHIE, Antony, TWAIL: Past and Future, International Community Law Review, v. 10, n. 4, p. 479-481, 2008; CHIMNI, Bhupinder S., Abordagens Terceiro-Mundistas para o Direito Internacional: um manifesto, Revista de Direito Internacional, v. 15, n. 1, 2018.a methodology, or both. It takes the mainstream positivist understandings of the concepts of \"theory \" and \"methodology \" seriously in order to assess TWAIL scholarship against those (admittedly contingent

15 Clara Kemme pointed that "W hile at present international law is accepted as a universal order, the study of its history is often geographically limited to Europe and thus strongly regionalized.". KEMME, Clara, The History of European International Law from a Global Perspective: Entanglements in Eighteen and Nineteenth Century India, in: DUVE, Thomas (Org.), Entanglements in Legal History: Conceptual Approaches, Frankfurt am Main: Max Placnk Institute for European Legal History, 2014, p. 490.

16 Taking two founders of discursivity as example, KOSKENNIEMI, Martti, The Gentle Civilizer of Nations. The Rise and Fall of International Law. 1870-1960, Cambridge: Cambridge University Press, 2004. and ANTONY ANGHIE, Imperialism, Sovereignty and the Making of International Law, Cambridge: Cambridge University Press, 2004. albeit dealing with themes like colonialism and imperialism, they both remained discussing Western authors and doctrines.

17 The number of studies specifically dealing with this region is much lesser in comparison with the Arab and Asian worlds; but it can be cited, for instance, the relevant works of OBREGÓN, Liliana, Construyendo la Región Americana: Andrés Bello y el Derecho Internacional, Revista de Derecho Público de la Universidad de Los Andes, v. 24, p. 1-22, 2010; OBREGÓN, Liliana, Creole Consciousness and International Law in Nineteenth Century Latin America, in: ORFORD, Anne (Org.), International Law and Its Others, Cambridge: Cambridge University Press, 2006, p. 247-264; OBREGÓN, Liliana, Carlos Calvo y la profesionalización del Derecho internacional, Revista Latinoamericana de Derecho Inter- national legal history that this essay modestly attempts to help fulfil.

\section{Pedro Autran da Matta Albuquerque AND KLÜBER'S DROIT DES GENS DE L'EUROPE: A HISTORY OF APPROPRIATION AND ADAPTATION}

'Elementos do Direito das Gentes' written by the professor at the Faculty of Recife, Pedro Autran da Matta Albuquerque, had been the first book about international law published in Brazil. ${ }^{18}$ It was one more book for the fertile intellectual production of the professor, who had written other four textbooks for at least four other disciplines, beyond other intellectual productions and translations. Pedro Albuquerque graduated from the University of Aix-en-Provence, mastering the French-language; skill that, together with his dedication to the teaching activity, allowed him to translate a few books from this language. In effect, he was a prolific writer. His works started with a translation of Stuart Mill's Principles of Political Economy ${ }^{19}$, prepared in 1832 to

nacional, p. 1-23, 2016; LORCA, Arnulf Becker, International Law in Latin America or Latin American International Law? Rise, Fall, and Retrieval of a Tradition of Legal Thinking and Political Imagination, Harvard International Law Journal, v. 47, n. 1, p. 283 305, 2006; LORCA, Arnulf Becker, Alejandro Alvarez Situated: Subaltern Modernities and Modernisms that Subvert, [s.l.: s.n.], 2006; SCARFI, Juan Pablo, El imperio de la ley. James Brown Scott y la construcción de un orden jurídico interamericano, Buenos Aires: Fondo de Cultura Económica, 2014; SCARFI, Juan Pablo, The Hidden History of International Law in the Americas: Empire and Legal Networks, Oxford: Oxford University Press, 2017.

18 There is only one book that it could be found the record, but not the physical book; thus, the content of it remained inaccessible. It is the 'Noções Elementares do Direito das Gentes para uso dos alumnus da escola militar' (1851) by Pedro Alcantara Bellegarde (1807-1864). The book is mentioned by JACOBINI, H.B., A Study of the Philosophy of International Law as Seen in Works of Latin American Writers, The Hague: Martinus Nijhoff, 1954, p. 153.; however, he could not see the book either. Even the National Library of Brazil did not have a copy of this book. According to the biographer Sacramento Blake, Pedro Alcantara Bellegarde had a military career, being Marshal and professor at the Military School. He wrote various books on mathematics to this school. Since he was not jurist, and his book had not been used in the law schools, the absence of the mentioned book is not a cause for concern and can be disregarded for the purposes of this essay. BLAKE, Sacramento, Diccionario Bibliographico Brazileiro. Vol. 1-7, Rio de Janeiro: Typographia Nacional, 1883, v. 7, p.8-11.

19 HALLEWELL, Laurence, O Livro no Brasil: Sua História, 
serve as a textbook for the discipline of Political Economy - what displeased the full professor of the chair. ${ }^{20}$ He also published Direito Natural Privado, a translation of Francisco Nobre Zeiller (sic) ${ }^{21}$ that had been used in the chair of the first year of the law school, as he after stated in the foreword of his Elementos de Direito Natural Privado.

In 1851, Pedro Autran would publish then his Elementos do Direito das Gentes, the first Brazilian textbook on international law. As it will be explored in this essay, the book to some extent set a tradition in the Faculty of Recife since the following two books on the subject, also written by professors, expressly took it as a reference and adopted the same division of contents.

Surely, Pedro Albuquerque was committed to accomplishing the assignment commanded by the statute that the professors should choose the appropriate textbook or compose one if inexistent. Considering that there was no book on international law in Portuguese-language, Pedro Albuquerque arranged his own.

However, that book published in 1851 by Pedro Autran Albuquerque was, in reality, an abridged translated version of a well-known book at the time - even in Brazil - published thirty years earlier: the 'Droit des gens moderne de l'Europe' by the German jurist and diplomat Johann Ludwig Klüber.

The first resemblance between the two books is the disposition and organisation of the topics. Pedro Albuquerque followed the same scheme established by Klüber, dividing the contents according to the rights of the States. The first part of both books was an introduction with preliminary notions, such as the concept of state, law of nations and sovereignty. Then, in the second part

2. ed. São Paulo: Editora da Universidade de São Paulo, 2005, p. 189. 20 BEVILAQUA, Clovis, História da Faculdade de Direito do Recife, Brasília: Instituto Nacional do Livro, Conselho Federal de Cultura, 1977, p. 36.

21 It is probably the translation of Franz von Zeillen's Das natürliche Privat-Recht, published in 1802. Preliminarily, it is unlikely that Pedro Autran could translate from German-language; judging by the way that he referred the author - Francisco Nobre Zeillen - and by the availability of the books, it can be assumed that he translated from an Italian version, since, by the 1830 s, that were already three editions of 'Il diritto privato naturale', by the so-called Francesco Nobile de Zeiller. In fact, the library of the Faculty of Recife has a copy of the Italian edition, published in Milan, in 1830, and translated by Giovanni Silvestri. About Zeiller, cf KOHL, G, Zeiller, Franz von (1751-1828), in: STOLLEIS, Michael (Org.), Juristen. Ein biographisches Lexikon. Von der Antike bis zum 20. Jahrhundert, München: Beck, 1995, p. 668-70. of Klübler's textbook, it came the rights of the States: a) Droit absolus des états de l'Europe entr'eux, b) Droits hypothétiques des états de l'Europe entr'eux, subdivided in b.1) Droits des états dans leurs rapports pacifiques, and b.2) Droits des états dans l'etat de guerre. ${ }^{22}$ By its turn, in the Albuquerque's book, the content was divided into the three following sections: a) Direito absolutos dos Estados, ${ }^{23} \mathrm{~b}$ ) Direitos condicionais dos Estados em suas relações pacíficas, ${ }^{24}$ c) Direitos dos Estados em suas relacõos hostis. ${ }^{25}$ The similarity between the two tables of contents is straightforwardly noticed; the only difference is that Pedro Albuquerque suppressed the references to Europe in his titles - by the way, he also did it within the text, eliminating almost all reference to States, wars and any other reference that could contextualise the law.

Klüber was part of a 'positivist' tradition, responsible for a particularisation of the international law, from the universal ius gentium to a regional ius publicum europaeum, as the titles of their books let clear. ${ }^{26}$ The particularisation had to do with the emergence and consideration of the treaty and the state practice as privileged sources of the law. In fact, from the end of eighteen century on, it will raise the number of authors focusing on state practice, forming a new branch of the law of nations, known as Droit public de l'Europe. ${ }^{27}$ As Wijffels comments:

Treaty practice gave rise, during the early-modern period,
to comparatively new genres of works. Diplomats wrote
extensively literary reports, or published original sources
(such as correspondence) with regard to negotiations which
they had attended. Collections of treaties, at first mostly
with respect to a particular nation, but later including
most European nations, grew within a few generations to
multi-volume scholarly editions of such primary sources
of diplomatic practice and international law. By the 18 th
century, when the first modern codifications appeared in the
domestic legal systems of some Western European countries,
these series of collected treaties were sometimes likened to the
'code' or 'statute-book' of the European law of nations.

22 KLÜBER, Johann Ludwig, Droit des gens moderne de l'Europe, Sttugart: J.G. Cotta, 1819, p. 9-10.

23 ALBUQUerQue, Pedro Autran da Matta, Elementos do Direito das Gentes, Recife: Typographia União, 1851. p. 6.

24 AlbUQUerQue, Pedro Autran da Matta, Elementos do Direito das Gentes, Recife: Typographia União, 1851. p. 16.

25 AlbuQUerQue, Pedro Autran da Matta, Elementos do Direito das Gentes, Recife: Typographia União, 1851. p. 53.

26 VEC, Miloš, Universalization, Particularization, and Discrimination . European Perspectives on a Cultural History of 19th century International Law, InterDisciplines, v. 2, p. 79-102, 2012, p. 84-86.

27 STEIGER, H., From the International Law of Christianity to the International Law of the World Citizen, Journal of the History of International Law, v. 3, n. 2, p. 180-193, 2001, p. 187.

28 WIJFFELS, Alain, Early-modern scholarship on international law, in: ORAKHELASHVILI, Alexander (Org.), Research Hand- 
The works of Georg Friedrich von Martens (17561821), Gabriel Bonnot de Mably (1709-1785), Johann Ludwig Klüber (1726-1837) were circumscribed within this context. From the consideration of a significant amount of data on state practice - Martens Recueil de Traités, for example, reached 126 volumes $^{29}$-, they extracted the principles and general rules of positive law of nations. This movement towards a systematization of the available sources at the international stage went along, by some means, with the process of codification of the law at the national level, in a similar pursuit for certainty, simplicity and systematicity for the multiplicity of scattered sources. In brief, their concern was practice; both as a source for their concept of law, as the audience that they were writing to. As Nuzzo summarised, that branch "nasceva dagli sforzi della diplomazia e ad essa era destinato.". ${ }^{30}$

Although the background of those authors could remain jusnaturalistic, it was the beginning of the loss of natural law's persuasive power ${ }^{31}$, and consequently, its characteristic universalism. By the same token, the consideration of state practice directed the foundations of international law towards a more regional normativity, applied only to those recognized as states and that shared common values. Miloš Vec pointed that "for the most of these authors the claim of Europeanism was so explicit and self-evident that they did not bother with many words of justification"; and it was the case of Klüber's textbook. ${ }^{32}$

Thus, Pedro Albuquerque had to omit the explicit references to Europe. The strategy may seem simple, but is symbolically remarkable, once with it, he was extending the validity of the international law beyond the particularised region theorised by Klüber, to include Brazil, and, as a consequence, universalising the international law once more. The facts that there was a

book on the Theory and History of International Law, Chelthenham, Nothampton: Edward Elgar Publishing, 2011, p. 47.

29 KOSKENNIEMI, Martti, Into Positivism: Georg Friedrich von Martens (1756-1821) and Modern International Law, Constellations: An International Journal of Critical \& Democratic Theory, v. 15, n. 2, p. 189-207, 2008, p. 195.

30 NUZZO, Luigi, Origini di una Scienza. Diritto internazionale e colonialismo nel XIX secolo., Frankfurt am Main: Vittorio Klostermann, 2012, p. 14.

31 KOSKENNIEMI, Into Positivism: Georg Friedrich von Martens (1756-1821) and Modern International Law.

32 VEC, Universalization, Particularization, and Discrimination . European Perspectives on a Cultural History of 19th century International Law, p. 86.
Monarchical regime in Brazil ${ }^{33}$ - with a European royal lineage -, and - besides the intricated relation between the Church and the new State - the Catholicism was conceived as the main religion, bonded the new Brazilian State to the European culture, facilitating its link to a legal system that was based on a common heritage and shared values. ${ }^{34}$ The Brazilian elite felt as inheritors of that culture. ${ }^{35}$

Following the tradition of Europeanism mentioned above, the first part of Klüber's treatise was dedicated to the history of European States, narrating its development and classifications. ${ }^{36}$ The Brazilian professor, though, skipped these chapters, going directly to the principles and rules of the law of nations.

From then onwards, Pedro Albuquerque followed precisely the contents as exposed by Klüber, each chapter and paragraph in the same order. As it will be exposed, he summarised the book of the German author, suppressing all the footnotes, simplifying more detailed explanations, and skipping some additional classifications. The footnotes played an important role on the 'Droit des gens moderne de l'Europe', because while in the text Klüber explained objectively the rights and rules of the law of nations, in the footnotes he used to make references to other works, and - most important - he contextualized the rules with real historical cases. Thus, by suppressing these notes, the book was turned in an objective and decontextualized exposition of norms of international law.

The most appropriate - and necessary - method to expose the similarities between the two texts is simply to compare them. Hence it will be quoted some passages from both texts. For example, when Pedro Albu-

33 SANTOS, Luís Cláudio Villafañe G., O Brasil entre a América e a Europa, São Paulo: UNESP, 2004, p. 35-38.

34 NUZZO, Origini di una Scienza. Diritto internazionale e colonialismo nel XIX secolo., p. 9-23.

35 It was a vivid feature of the Brazilian legal culture in the nineteenth-century, where jurists simultaneously sought its own identity and autonomy, yet always endorsing the European pattern. As Joaquim Nabuco (1849-1910), a notorious jurist, politician, and diplomat, writing in 1893, felt: "O sentimento em nós é brasileiro, a imaginação europeia.". And yet: "Nós brasileiros - o mesmo podese dizer dos outros povos americanos - pertencemos à América pelo sedimento novo, flutuante do nosso espírito, e à Europa, por suas camadas estratificadas. Desde que temos a menor cultura, começa o predomínio destas sobre aquele.”.NABUCO, Joaquim, Minha formação (1893), Rio de Janeiro: Nova Fronteira, 2015, p. 58, 57.

36 KLÜBER, Johann Ludwig, Droit des gens moderne de l'Europe, Sttugart: J.G. Cotta, 1819. p. 24-68. 
querque, in the chapter about the treaties, explains the essential conditions to the validity of a treaty, he used these words:

O consentimento reciproco e livre das partes contractantes he huma condição essencial a validade de todo o tratado. Não ba verdadeiro consentimento, se elle foi dado por erro, ou por dolo. Para haver consentimento be necessario que a promessa feita por huma das partes seja acita pela outra. $O$ consentimento be livre, se não foi extorquido por buma violencia injusta. A violência em defeza de bum direito, quando não passa dos limites que o exercício do direito exige, não vicia o consentimento. ${ }^{37}$

Whereas Klüber, for the same topic, wrote the following:

Le consentement libre et réciproque, expresse on tacite, des différentes parties contractantes, eu aussi une condition essentielle pour la validité d'un traité public. En conséquence, de simples négociations, des communications purement préparatoires, ne sont, d'après leur nature même, nullement obligatoires. Il n'y a point de vrai consentement non plus, s'il a été donné par erreur, ou si la partie a été surprise par dol, pourvu que dans ce dernier cas elle ait été uniquement déterminée par les mancouvres pratiquées; la lésion de l'une des parties en cas d'échange, résultante de la différence de valeur en argent des objets échangés, ne vient point en considérations..$^{38}$

It can be noticed that, in the case above, Pedro Albuquerque followed the same reasoning, although without using exactly the same words. Nevertheless, other passages, such as the following, that apparently are a literal translation of Klüber's text:

He tambem necessario, para que bum tratado obrigue buma nação, que a promessa por ella feita se possa cumprir, isto be, que não haja impossibilidade physica, ou moral de a cumprir. A impossibilidade he physica, quando, bum dos pactuantes se obriga ao que não pode satisfazer, por the faltarem meios physicos dependentes da sua vontade. Haveria impossibilidade moral se o cumprimento da promessa offendesse direitos de terceiro. ${ }^{39}$

While in Klüber's 'Droit des gens moderne de l'Europe':

Il faut encore pour qu'un traité oblige les parties contractantes, que les promesses données de part et d'autre puissent être remplies. a) Il ne doity avoir impossibilité de l'exécution, ni physique ni morale. Une clause physiquement impossible à exécuter serait celle, à laquelle celui qui s'y serait engagé ne pourrait nullement satisfaire, faute de moyens physiques dépendans de lui. Il y aurait impossibilité morale, si

37 ALBUQUerQue, Pedro Autran da Matta, Elementos do Direito das Gentes, Recife: Typographia União, 1851. p. 22.

38 KLÜBER, Johann Ludwig, Droit des gens moderne de l'Europe, Sttugart: J.G. Cotta, 1819. p. 226.

39 AlBUQUerQue, Pedro Autran da Matta, Elementos do

Direito das Gentes, Recife: Typographia União, 1851. p. 23. l'accomplissement de la promesse devait entraîner la lésion des droits d'un tiers. ${ }^{40}$

Beyond the undeniable likeness among the two quotes, what is most remarkable in this passage is that Pedro Albuquerque even highlighted the phrase identically as Klüber did in his book: 'promessa por ella feita se possa cumprir' and 'les promesses données de part et d'autre puissent être remplies'. In other cases, the Brazilian author chose to summarize the idea instead of simply translating Klüber's narrative. So, Pedro Albuquerque initiated in a similar way, then avoided the detailed explanation from the original; like the next quotation:

O tratado de garantia he hum dos contractos internacionaes
mais usuaes. He o contracto pelo qual hum Estado promette
ajudar outro, se for interrompido, ou ameaçado de ser
perturbado por outra potencia no gozo pacifico de tal ou tal
direito. A garantia he applicavel a toda a especie do direito:
á posse e aos limites dos territorios, á soberania do Estado,
á constituição do seu governo, aos direitos de sucessão, etc.,
porém mais commummente aos tratados de pa\%. Pode
tambem conter-se em huma convenção distincta e separada,
ou ser comprehendida no mesmo tratado principal. ${ }^{41}$

As can be seen, the wording of Klüber for the same topic was more extensive:

L'une des plus usitées des conventions dont nous nous
occupons, est la garantie a) proprement dite, par laquelle un
état promet de prêter secours à un autre état, dans le cas que
celui-ce serait lésé ou menacé d'un préjudice dans l'exercice
de certains droits b), par le fait d'une tierce puissance.
La garantie est toujours promise par rapport à une tierce
puissance, de la part de laquelle il pourrait être porté
préjudice à des droits acquis. Elle peut donc être admise,
comme moyen de sûreté, dans toute obligation existante entre
deux ou plusieurs états c), bors le garant; nommément dans
celles résultantes du voisinage et de la situation ou possessions
des territoires, de la souveraineté, de la constitution de l'état,
du droit de succession au trône, etc. d) Elle est la plus usitée
cependant dan les traités de paix. e) La formation du contrat
de garantie dépend de la libre volonté du garant, et de la
puissance à qui elle est promise. La promesse peut être fait
non-seulement à la puissance dont elle garantit les droits
mais aussi, en faveur de celle-ci à une tierce puissance. f) De
même, l'obligation de conclure le traité de garantie avec une
puissance, peut être établie par un traité avec un autre. Le
consentement de celui contre lequel la garantie est stipulée,
n'estpoint requispour sa validité; cependant ilpeut être utile
qu'il en ait connaissance.

The same strategy can be seen in the next passage, where Pedro Albuquerque suppressed some phrases,

40 KLÜBER, Johann Ludwig, Droit des gens moderne de l'Europe, Sttugart: J.G. Cotta, 1819. p. 228.

41 ALBUQUerQue, Pedro Autran da Matta, Elementos do Direito das Gentes, Recife: Typographia União, 1851. p. 28.

42 KLÜBER, Johann Ludwig, Droit des gens moderne de l'Europe, Sttugart: J.G. Cotta, 1819. p. 247. 
without changing the general idea:

\begin{abstract}
Quando bum tratado publico apresenta hum sentido dubio, a interpretação authentica não pode ser dada senão pelas mesmas partes contractantes, ou por aquelle em quem ellas se lowvão. O terceiro escolbido para interpretar o tratado deve firmar-se nas regras geraes da interpretação. ${ }^{43}$
\end{abstract}

Lorsqu'un traité public présente un sens douteux, il ne peut recevoir d'interprétation authentique que par une déclaration des parties contractantes, ou de ceux, à l'arbitrage desquels elles en ont appelé. La question préalable même, de savoir si le sens est douteux, ne peut être décidée que par une pareille convention. L'interprétation faite immédiatement par les parties contractantes, peut être revêtue de toute forme qui constitue en général la validité d'un traité public; elle peut se faire particulièrement dans un recez supplémentaire ou traité explicatif. a) Le tiers, au jugement duquel l'interprétation est soumise, doit s'appuyer des règles générales de l'interprétation grammaticale et logique. ${ }^{44}$

Conversely, some other topics were fully and simply translated, without adaptations, even larger passages. ${ }^{45}$

43 AlbUQUerQue, Pedro Autran da Matta, Elementos do Direito das Gentes, Recife: Typographia União, 1851. p. 33.

44 KLÜBER, Johann Ludwig, Droit des gens moderne de l'Europe, Sttugart: J.G. Cotta, 1819. p. 258.

45 As can be observed here: "Os ministros publicos gozão de certas prerrogativas derivadas do direito das gentes, tanto natural como positivo. Huma das mais importantes he a inviolabilidade. Desde que hum governo reconhece-o publicamente hum ministro estrangeiro como representante immediato do seu soberano, toda a violação dos direitos ineherentes a essa qualidade, commetida no seu territorio, deve considerar-se como offensa ao soberano do ministro. He por conseguinte muito do interesse do governo, não só prevenir, quanto puder, toda a violação desta especie, como tambem punil-a severamente, se ella se der. O estado de maior segurança, que daqui resulta para o ministro, constitue a sua inviolabilidade, ou também considerar esse estado de segurança como cousa sagrada. Esta inviolabilidade, ou protecção particular, he devida aos ministros das tres classes. Ella estende-se a todos os actos do ministro em razão do seu officio; e, segundo o direito das gentes moderno, he respeitada até em caso de rompimento com o seu governo, e depois de já começadas as hostilidades." ALBUQUERQUE, Pedro Autran da Matta, Elementos do Direito das Gentes, Recife: Typographia União, 1851. p. 42. Just like Klüber wrote: "Les ministres publics jouissent de certaines prérogatives dérivées du droit des gens, tant naturel que positif. a) L'une des plus importantes c'est leur inviolabilité. Dès qu'un gouvernement a publiquement reconnu un ministre étranger en sa qualité de représentant immédiat de son souverain, toute violation des droits attachés à cette qualité b), qui est commise dans son territoire, doit être considérée comme une offense faite au souverain du ministre même. Il est par conséquent fort l'intérêt du gouvernement, non seulement de prévenir, autant que possible, toute violation de cette espèce, mais aussi de la punir sévèrement comme délit contre l'état, si néanmoins elle aurait eu lieu. L'état de plus grande sûrete que en résulte pour le ministre, s'appelle son inviolabilité, dans le sens éminent ou du droit des gens c) ou bien aussi la sainteté du ministre, parce qu'il est de l'intérêt commun des nations d'envisager cet état de sûrete comme une chose sacrée. Cette inviolabilité ou protection particulière, est due aux ministres des trois classes. d) Elle s'étend sur toute l'activité officielle du ministre, et principalement sur ses fonctions diplomatiques, e) un entier
This considerable quantity of quotations makes clear that examples of very similar writing can be found over the entire book; the following passage, just to illustrate it, is almost in the end of Pedro Alquerque's textbook:

\begin{abstract}
Huma clausula essencial aos tratados de paz, e que por conseguinte está subentendida, quando não be expressa, be a amnistia. Entende-se por aministia a declaração de ambas as partes, pela qual considerão suas inimisades como completamente terminadas e abolidas, e promettem reciprocamente esquecer-se do que motivou a guerra, e dos males que esta lhes causou, para nunca mais servirem de causa, nem pretexto para buma nova guerra. ${ }^{46}$

Une clause essentielle dans tout traité de paix, et par conséquent supposée tacite, si elle n'est point exprimée et que le traité n'en dispose autrement, c'est l'amnistie a) (lex oblivionis). On entend par-là la déclaration de deux parties d'après laquelle elles regardent leurs inimitiés comme entièrement terminées et abolies, et se promettent réciproquement qu'elles ne serviront jamais de cause ni de prétexte à une nowvelle guerre. Ce qui n'a point été cause, ni objet de la guerre, n'est point compris dans l'amnistie. ${ }^{47}$
\end{abstract}

Once it was not a declared translation, Pedro Albuquerque was free to manipulate the text and choose which part he would use and which he would skip. In this path, he could suppress all the footnotes and some depth explanations, turning a book with more than five-hundred pages in a less than hundred pages book. Whereas a genuine translation requires to some extent an adherence to the original text, ${ }^{48}$ the work implemented by Pedro Albuquerque liberated him from the mandatory loyalty to the translated book.

The Droit des gens moderne de l'Europe, in fact, is deeply based on previous works and cases, either to support his arguments, as to show contrary opinions. Conversely, in the Elementos do Direitos das Gentes, Pedro Albuquerque barely mentioned other works; there are only some references to Schmalz, ${ }^{49}$ Vattel, ${ }^{50}$ Bynkershoek. ${ }^{51}$ However,

sauf-conduit lui est dù pendant tout son voyage, passage, et séjour officiels dans le territoire de l'état f), même lorsque la guerre entre les deux états aurait éclaté." KLÜBER, Johann Ludwig, Droit des gens moderne de l'Europe, Sttugart: J.G. Cotta, 1819. p. 320.

46 ALBUQUerQue, Pedro Autran da Matta, Elementos do Direito das Gentes, Recife: Typographia União, 1851. p. 86.

47 KLÜBER, Johann Ludwig, Droit des gens moderne de l'Europe, Sttugart: J.G. Cotta, 1819. p. 500.

48 FIOCCHI MALASPINA, Elisabetta; KELLER-KEMMERER, Nina, International Law and Translation in the 19th century, Rechtsgeschichte, v. 22, p. 214-226, 2014, p. 216.

49 Theodor Anton Heinrich Schmalz (1760-1831). ALBUQUERQUE, Pedro Autran da Matta, Elementos do Direito das Gentes, Recife: Typographia União, 1851. p. 19, 35.

50 ALBUQUERQUE, Pedro Autran da Matta, Elementos do Direito das Gentes, Recife: Typographia União, 1851. p. 30.

51 Cornelius van Bynkershoek (1673-1743). ALBUQUERQUE, 
even those few can be just copied from Klüber, due to the similarity between the footnotes:

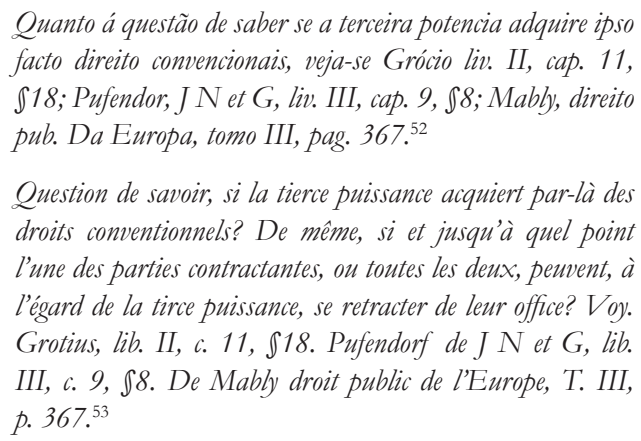

In the back cover of the book, the full title was Elementos do Direitos das Gentes, according to the writings of modern authors, composed by Dr. P. Autran da Matta Albuquerque'. The subtitle - according to the writings of modern authors - could indicate that the book was a compilation or compendium, a widespread genre of book at that time in Brazil, in which the author assembles and digests a considerable quantity of other authors in order to compose a synthetic panorama of the discipline and its doctrines. In fact, this kind of literary genre caused some controversies in Brazil, where some books on the history of Brazil were accused of plagiarism due to some resemblances to another author, without the proper reference to the original texts. ${ }^{54}$ The very first - published in 1832 - and the most known book of international law in the Latin America for the nineteenth century, the 'Principios de derecho de jentes' by Andrés Bello, was an elegant and declared compilation of European authors, still being original, as Liliana Obregón stated.$^{55}$ Apparently, this was not the case of Pedro Al-

Pedro Autran da Matta, Elementos do Direito das Gentes, Recife: Typographia União, 1851. p. 76.

52 ALBUQUerQue, Pedro Autran da Matta, Elementos do Direito das Gentes, Recife: Typographia União, 1851. p. 32.

53 KLÜBER, Johann Ludwig, Droit des gens moderne de l'Europe, Sttugart: J.G. Cotta, 1819. p. 257-258.

54 SANTOS, Pedro Afonso Cristovão dos, Compilação e plágio: Abreu Lima e Melo Morais lidos no Instituto Histórico e Geográfico Brasileiro, Revista da História da Historiografia, v. 13, p. 45-62, 2013.

55 "Desde el inicio, Bello informa a sus lectores que su obra no es original, sino un repertorio bien organizado de las obras de muchos autores. Se presenta como un editor ilustrado y selectivo que, según su propia descripción, adopta, revisa, discute, cita, prueba, presenta, contradice y reescribe las obras de los autores que ha consultado. Podríamos decir que Bello conversa con estos autores a lo largo del libro y mediante la edición cuidadosa, la homogenización del lenguaje y estilo, y la adición de múltiples pies de página, nos proporciona, de hecho, una voz autorizada sobre sus ideas. Incluso, la selección de textos que resume o reescribe (a menudo sin citarlos) hace difícil distinguir si se encuentra editando más de lo que buquerque, since he did not resort to other authors but Klüber, and also, as it would be expected from a compilation, he did not mention the German author in any part of his book.

Nevertheless, it should be reminded that Klüber's Droit des Gens Moderne de l'Europe was a marketed book in Brazil, and above all, it was adopted for the teaching of the discipline in the law faculties at that time. As a research on the Brazilian newspapers of the first half of nineteenth century showed, Klüber's book began appearing in Brazil by $1836,{ }^{56}$ thenceforward it became constantly offered in the advertisements of booksellers. ${ }^{57}$ One remarkable announcement, issued in 1850 in a newspaper of Recife ${ }^{58}$ - that is, the same city where it was published Pedro Albuquerque's book, and just one year before its publication - did enunciate: "For sale, the much-sought out book Droit des gens by Klüber, in two new volumes, for the second year of the law faculty. Fair price.".

Under these circumstances, one cannot assume that it was not widely known that the Elementos do Direitos das Gentes was indeed a shortened translation of Klüber; and not a case of deliberate plagiarism. Additionally, the books written by his fellow professors Antonio Drummond and João Silveira de Souza mentioned both Klüber and Pedro Albuquerque; it is very unlikely that they had not noticed the resemblance between them. In this context, one hypothesis is that, facing a great demand of Klüber's book, Pedro Albuquerque tried to help his students translating and summarizing the German author; however, since the result was not a literal translation, and he modified several passages, he could not attribute the authorship to Klüber, but to modern authors in general.

An aspect that draws attention in this peculiar case

reconoce en su prólogo o si realmente lo que está escribiendo es un texto original14. Bello, como parte de su conciencia criolla, ve los textos extranjeros como un legado intelectual del que él (y los demás criollos) es heredero legítimo y del que puede apropiarse con toda libertad, como nuevo miembro de la comunidad de ciudadanos de las naciones independientes." OBREGÓN, Liliana, Construyendo la región americana: Andrés Bello y el Derecho Internacional, in: CHOPO, Yolanda Gamarra (Org.), La idea de América en el pensamiento ius internacionalista del siglo XXI, Zaragoza: Institución Fernando El Católico, 2010, p. 69-70.

56 Diario de Pernambuco. No 91. 26 April 1836.

57 Diario de Pernambuco. No 101.10 May 1837. Diario Novo. $N^{\circ}$ 69. 29 March 1845. Diario de Recife. $N^{\circ}$ 54. 4 March 1868. Correio Paulistano. $N^{\circ} 250.3$ May 1855

58 Diario de Pernambuco. No 169. 31 July 1850. 
- in which the very first Brazilian book on international law is, in fact, a summarized translation of Klüber's treatise - is the method, and easiness withal, that Pedro Albuquerque, a non-European jurist from a newly independent State, appropriated a European discourse and made it as his own. It seems paradoxical that precisely the most particularised conception of international law - that one of Klüber, Martens, Schmalz - happened to be appropriated by a peripheric jurist, who by doing it, was spreading and disseminating the international law.

As shown, the Brazilian author extensively and without reluctance manipulated the original text to his interest: to elaborate a short textbook with a concept of international law that could be accepted in Brazil. Thus, the work of Pedro Albuquerque was far beyond a mere reproduction of a text from one language to another, he was somewhat promoting a cultural translation, by adapting and accommodating exogenous ideas to his context. ${ }^{59}$ In other words, it was not just a matter of different lexicon, as a mechanical and passive process, instead, Pedro Albuquerque acted as a mediator ${ }^{60}$ between diverse cultures in an intricate process of appropriation and assimilation. As Lena Foljanty explains:

In legal historical analysis, the concept of cultural translation invites us to look at the processes of adopting foreign ideas

59 "La traduzione, intesa nel suo significato più ampio, non solo di formulare in una altra lingua il testo originale, ma anche di « portare al di là » (《 trans » - « oltre », e « ducere » - «portare »), ha senz'altro giocato un importante ruolo. Tradizionalmente rilegata ad essere semplicemente oggetto di prefazioni, introduzioni, note del traduttore, è invece stata l'anello di congiungimento nel processo di professionalizzazione del diritto internazionale. I traduttori, esattamente come i giuristi, possono essere dipinti come mediatori e diplomatici perché erano chiamati in prima persona a gestire problemi di enorme distanza culturale, linguistica, di tempo, di spazio ed erano gli agenti centrali delle idee e dei valori europei." FIOCCHI MALASPINA, Elisabetta, L'eterno ritorno del Droit des gens di Emer de Vattel (scc. XVIII-XIX), Frankfurt am Main: Max Planck Institute for European Legal History, 2017, p. 255.

60 "Così la costruzione identitaria degli stati europei e non europei genera una esigenza di traduzione come forma di appropriazione, ma anche di identità, bilanciata con quelle che sono le interazioni derivanti dalle diversità culturali e sociali. La figura del mediatore (giuridico) venne svolta concretamente da coloro che si occupavano di diritto internazionale. I giuristi presero attivamente parte al processo di costruzione del diritto (internazionale) e ne favorirono l'espansione. Il risultato fu sostanzialmente qualcosa di profondamente diverso dalla classica e statica rappresentazione del diritto internazionale come sapere a dimensione universale, ma al contrario provvide a esaltarne la specificità, svelando, attraverso le sovrapposizioni tra piano statale e interstatale e il dinamico intreccio tra culture, società, diritti, e linguaggi, il suo carattere ibrido." FIOCCHI MALASPINA, Elisabetta, L'eterno ritorno del Droit des gens di Emer de Vattel (scc. XVIII-XIX), Frankfurt am Main: Max Planck Institute for European Legal History, 2017. p. 256. and norms not from a bird's eye perspective, but rather from within. Translation means to develop an idea of the other and to reformulate these ideas in order to make them accessible in the new context. It is a process in which meaning shifts, decisions are taken and negotiations take place. ${ }^{61}$

Lydia Liu resorts to the image of the translator as a diplomat, in the sense that he negotiates in multiple directions, producing considerable changes in the original text. ${ }^{62}$ In fact, the analogy is useful to understand the work implemented by the Brazilian author, who negotiated with the text in order to be well received in the Brazilian context.

For example, although he generally followed each chapter and in the same order as the Klüber's treatise, he completely and deliberately ignored the paragraph that dealt with the abolition of the slave trade, where Klüber condemned it. ${ }^{63}$ The theme, in fact, was extremely delicate in Brazil, and it was one of the main diplomatic issues, causing severe contentions with Great Britain for the first half of the century. ${ }^{64}$ The most critical period was precisely by the time that Pedro Albuquerque was publishing the book, after the Bill Aberdeen Act. The British diplomatic policy against the slave trade, strict, unilateral and intervening, was frequently interpreted as a way to undermine the Brazilian economy, affecting the national pride directly, as indicated another author of that period, Antonio Pereira Pinto. ${ }^{65}$ Thus, it was doubtful that Pedro Albuquerque would reproduce that the

61 FOLJANTY, Lena, Translators: Mediators of Legal Transfers, Rechtsgeschichte, v. 24, p. 120-121, 2016, p. 120.

62 LIU, Lydia H., The Clash of Empires. The Invention of China Modern World Making, Cambridge: Harvard University Press, 2004, p. 113.

63 KLÜBER, Johann Ludwig, Droit des gens moderne de l'Europe, Sttugart: J.G. Cotta, 1819. p. 115-117.

64 CERVO, Amado Luiz; BUENO, Clodoaldo, História da política exterior do Brasil, 5. ed. Brasília: Editora Universidade de Brasilia, 2015, p. 89-93; BETHELL, Leslie, The abolition of the Brazilian slave trade: Britain, Brazil and the slave trade question (1807-1869), Cambridge: Cambridge University Press, 1970.

65 "As violencias do cruzeiro inglez plantárão no Brasil uma reacção inversa da que se devêra desejar: o espirito publico, resentido dos ataques à independencia da nação, presuppunha o governo do paiz sob a pressão da Grã-Bretanha, e a esssa pressão atriuibuia as medidas que tomava para a repressão do trafego, conjecturando, além disso, que os esforços da Inglaterra para acabar com o commercio de escravos tendião a fazer definhar a nossa lavora, em vantagem das colonias britannicas; por outro lado, os rapaces contrabandistas, explorando estas erradas apprehensões dos lavradores brasileiros, demandavão, ousados, as costas do Imperio, e nellas despejavão unnumeros carregamentos de Africanos boçaes, aos quaes achavão prompta, e lucrativ sahida." PINTO, Apontamentos para o Direito Internacional. v. 1, p. 365-366. 
slave trade was forbidden by the international law because it would inevitably generate commotion in Brazil, and as a consequence, discredit of his book.

Apart from these suppressions, the apparent easiness that occurred the mediation - between a particularised and often discriminatory notion of international law, and the Brazilian context - was due to the condition of lettered criollo held by Pedro Albuquerque. As pointed by Liliana Obregón, the creole consciousness permitted that the Latin American jurists conceived the European law as something appropriable, since they recognised themselves as legitimate inheritors of the Western culture. ${ }^{66}$ This means that, in Pedro Albuquerque's mind, the expansion of the European law to include Brazil, that he was implementing with his work, was not something forced and contrived; it was rather just a claim of an evident and natural flow. As already indicated, he only had to eliminate the specific references to Europe and rectify the particularisation that could exclude Brazil, and then present the text as written by himself - which without doubts played an important role to promote the assimilation of the European normativity as something universally valid.

\section{The hybridization continues: Antônio Menezes Vasconcelos de Drummond and JoÃo SiLVEIRA de Souza}

The project of mediation was continued and propelled by Antônio Menezes Vasconcelos de Drummond, the author of the second textbook on international law published in Brazil, and a professor at the Faculty of Recife also. His book had been published in 1867 under the title 'Preleções de Direito Internacional'. Already in the preface, he anticipated to the reader that he aimed to bring Pedro Albuquerque's book up-to-date - since it had been published fourteen years earlier - according to the new developments of this 'science', "in constant progress, so as the civilisation" ${ }^{67}$ His announcement is

66 OBREGÓN, Liliana, Construyendo la Región Americana: Andrés Bello y el Derecho Internacional, Revista de Derecho Público de la Universidad de Los Andes, v. 24, p. 1-22, 2010. p. 67.

67 "Quando em 1865 tive de substituit o illustrado Lente Cathedratico da Faculdade de Direito o Sr. João Silveira de Souza, encontrei seus Alumnos nas primeiras lições dos Elementos de Direitos das Gentes - compostos, e publicados em 1851, pelo Sr. Conselheiro Dr. Pedro Autran da Matta Albuquerque, Venerando needless though; as it becomes evident at first glance in the structure of the book, that he adopted the very same chapter division as Pedro Albuquerque's book, and so, the same as Klüber. It begins with an introduction of preliminary notions and concepts, ${ }^{68}$ followed by these sections: a) Dos Direitos absolutos dos Estados, ${ }^{69}$ b) Dos Direitos Hypotheticos, ou condicionais dos Estados em sus relações pacificas, ${ }^{70} \mathrm{c}$ ) Dos Direitos dos Estados em suas relações bostis, ${ }^{71}$ - until here, he followed exactly the book of his colleague; however, as Drummond wanted to explore more some themes, he created the following autonomous sections, ${ }^{72}$ which were all part of the last section in Pedro Albuquerque's book -, d) Dos Meios empregados no mar durante a guerra, ${ }^{73}$ e) Dos meios empregados na guerra continental, ${ }^{74}$ and finally, f) Dos meios tendentes a manutenção das boas relaçôes. ${ }^{75}$

Even though Antonio Drummond had adhered to the same structure of Pedro Albuquerque's book, he did elaborate his own text, often developing more a particular topic, or just by varying the wording used by his colleague, yet passing the same idea. ${ }^{76}$

Decáno da mesma Faculdade. E pois para texto, e ordem das minhas Prelecções sobre essa materia continuei à adoptar aquelle Compendio. Reconheci porém, que esse recommendavel trabalho (seja-me licito dizê-lo com franqueza) já ressentia-se de algumas lacunas inherentes ao longo período de 14 annos, que havia decorrido desde a sua publicação, e necessariamente muito deveria ter influido sobre as doutrinas d'essa sciencia de tão rápido desinvolvimento, e constante progresso, como a propria civilisação.” DRUMMOND, Preleções de Direito Internacional. p. 5.

68 DRUMMOND, Preleções de Direito Internacional. p. 9-14.

69 DRUMMOND, Preleções de Direito Internacional. p. 1542.

70 DRUMMOND, Preleções de Direito Internacional. p. 43104.

71 DRUMMOND, Preleções de Direito Internacional. p. $105-144$.

72 "Procurei portanto supprir essas involuntarias omissões, lançando os primeiros traços da obra, que se segue, para o que não poupei aturada paciencia, exforços, e vigilias - comtanto maior difficuldade, quando me era imposto o dever de seguir o methodo elementar.” DRUMMOND, Preleções de Direito Internacional. p. 5.

73 DRUMMOND, Preleções de Direito Internacional. p. $145-188$.

74 DRUMMOND, Preleções de Direito Internacional. p. 189-200.

75 DRUMMOND, Preleções de Direito Internacional. p. 201-219.

76 As it can be noticed in the following example; in the $\$ 6 \square$ of Pedro Albuquerque's textbook: "Os direitos das nações e dos individuos fundão-se nos mesmos principios; e como fundamentos de huns e de outros se podem estabelecer as seguintes verdades morais: 1. Todo ente moral quer seja indivduo, quer nação, tem o direito de 
Thus, a somewhat similarity can be ascertained between his 'Preleções de Direito Internacional' and the 'Elementos do Direitos das Gentes' by Pedro Albuquerque; as a consequence, Klüber's treatise still being the main inspiration for the Brazilian professors. This time, however, Drummond went beyond the reference of Klüber, resorting to a variety of other foreign authors to draw up his conclusions. Unlike his predecessor, Drummond did mention Klüber ${ }^{77}$ in his book - including the most recent edition of 1861 - and other contemporary authors, such as Georg Friedrich von Martens, ${ }^{78}$ Henry Wheaton, ${ }^{79}$ Theodor Schmalz, ${ }^{80}$ August Wilhelm Heffter, ${ }^{81}$ Silvestre Pinheiro Ferreira, ${ }^{82}$ Laurent-Basile Hautefeuille. ${ }^{83}$ Indeed, the bibliography consulted indicates that Antonio Drummond revised Pedro Albuquerque's book updating with the most recent doctrine on international law. ${ }^{84}$

se conservar, aperfeiçoar e promover a sua felicidade; 2 . Ninguem pode locupletar-se, nem avantajar-se com lesão do direito do outro; 3. Quem lesa o direito alheio está obrigado a reparação; 4. As convenções livremente feitas entre pessoas capazes de contractar, e sobre objeto lícito, ligão as partes contractantes." ALBUQUERQUE, Elementos do Direito das Gentes. p. 4. While Drummond wrote like this: "Sendo as nações verdadeiras pessoas moraes, ou associações de individuos - gosam, como estes, dos mesmos direitos baseados em idênticos princpipios de severa justiça, e pura moral - a saber. 1. Todo o ente moral, quer seja individuo, quer nação, tem o direito de se conservar, aperfeiçoar e promover sua felicidades; 2. Ninguém pode locupletar-se, nem avantajar-se com a jactura alheia; 3. A reparação é sempre devida e cabe effetua-la pelo modo mais prompot - áquelle que offende ou prejudica o direito alheio; 4. As convenções celebradas por pessôas habeis, ou capazes de contractar e sobre o objetcto lícito tem entre essas mesmas partes toda força obrigatória." DRUMMOND, Preleções de Direito Internacional. p. 12.

77 DRUMMOND, Preleções de Direito Internacional. p. 10, 30.

78 DRUMMOND, Preleções de Direito Internacional. p. 30, 139.

79 DRUMMOND, Preleções de Direito Internacional. p. 30, $61,64,72,160,210$

80 DRUMMOND, Preleções de Direito Internacional. p. 30. 81 DRUMMOND, Preleções de Direito Internacional. p. 30, $41,55,61,160,194$

82 DRUMMOND, Preleções de Direito Internacional. p. 30, $50,91,121,126$

83 DRUMMOND, Preleções de Direito Internacional. p. 72, 176,209

84 "Julguei ainda conveniente prescindir de frequentes citações dos Escriptores que consultei para confecção deste meu trabalho, não só paa não distrahir aos laumnos (para quem principalmente emprehendi-o) com extranhas considerações, em pura perda do estudo das proposições geraes, e poupar a mim mesmo essa ardua tarefa, senão também por parecer-me, que o verdadeiro merito dessas respeitaveis autoridades não póde por certo depender do testemunho dado á cada passo, e á cada instante. Por isso preferi menciona-las no fim desta Obra, como mais uma garantia para ella.
Besides that, the originality of Drummond's textbook resides in his intention to nationalise the teaching of international law, ${ }^{85}$ which meant contextualise the rules and principles of international law according to the Brazilian experience and legislation. Thus, he accomplished the task, either by referring in the footnotes to the specific Brazilian legislation related to the topic or by mentioning the treaties signed by Brazil and also the diplomatic cases that exemplified the rule. ${ }^{86}$

Whereas Pedro Albuquerque decontextualized the European international law in order to eliminate the particularisations and then permit the inclusion of Brazil in the international legal community, Antonio Drummond, advancing the project of appropriation and dissemination of the European normativity, tried to relate it to the Brazilian experience. With this, Drummond was taking a significant step towards the assimilation of the international law in Brazil, thereby promoting the universalisation of this legal system. As suggested by Eduardo Zimmermann, focusing the paratext - this is, the prologues and introductions, footnotes and commentaries - permits to "appreciate how the work of these "mediators" generated a process of hybridization of knowledge" 87 . This is exactly what happens here;

Quando por ventura não bastar esta satisfação, que entendi ser devida pedirei, que se leve tambem em conta o penoso trabalho, que tive de compulsar, numerosa Obras e dellas deduzir o que me pareceu mais racional, e ajustado, procurando com acurado emprenho coôrdenar as doutrinas, de que me apropriei, e as reflexões com que as revesti - para torna-las mais adaptadas ao ensino, a que as applico, sm alias sacrificar a clareza e precisão necessarias." DRUMMOND, Preleções de Direito Internacional. p. 6.

85 "Tendo sempre considerado ser de indeclinavel necessidade nacionalisar o mais possível o ensino do direito nas nossas Faculdades, já conforntando os seus principios com a Legislação Brazileira, já comparando as suas disposições com as das Nações cultas, já emfim commentando-as; methodo seguido com maxima proficuidade nas Faculdades Juridicas da Europa - especialmente recommendado pelo art. 3 - Do Decreto n .1 .333 de 23 de março de 1853 (os anteriores Estatutos), producrei addicionar ao ensino d'essa sciencia a referencia e applicação dos seus principios á nossa Legislação patrica." DRUMMOND, Preleções de Direito Internacional. p. 5-6.

86 "Occupei-me - ainda que rapidamente - da apreciação de todos os Tratados e Convenções, que o Brazil tem celebrado com as diversas Nações até a actualidade. Para melhor ordem - consagrei no texto da obra as doutrinas ou preceitos geraes da sciencia, collocando anotações convenientes a designação da Lei, do Tratado, da Convenção ou a ommemoração emfim do facto historico, que devia autorisar as mesmas doutrinas.”. DRUMMOND, Preleções de Direito Internacional. p. 6.

87 ZIMMERMANN, Eduardo, Translations of the "American Model" in Nineteenth Century Argentina: Constitutional Culture as a Global Legal Entanglement, in: DUVE, Thomas (Org.), En- 
the adding of contextualized footnotes with Brazilian contents promotes a mixture of local and European knowledge, which refutes the traditional conception of diffusion whereby ideas and doctrines were simply disseminated from the West to the rest of the world ${ }^{88} \mathrm{In}$ other words, the work of those mediators, such as Drummond, shaped a hybridization of knowledge rather than a passive acceptance of a selected doctrine.

Antonio Drummond also used the footnotes to express his opinions on diplomatic issues, occasionally being quite critical - which was also another novelty for textbooks. For example, when he relates briefly all treaties that had been signed by Brazil until then, ${ }^{89}$ he did not avoid to censure the British policy, and, naturally, the Bill Aberdeen Act. ${ }^{90}$ With the 'Prelecções de Direito Internacional' the students were provided with a more complete and substantial textbook than the previous one.

The subsequent work on international law, and the last one considered in this essay, would come twenty-two years later, in 1889, the last year of the Imperial regime. 'Lições de Direito das Gentes' had been written by another professor of Recife, João Silveira de Souza. In the same pattern, it was a book designed to teach the discipline ${ }^{91}$ and inspired in Elementos do Direito das Gentes' by Pedro Albuquerque as well:

Tendo adoptado para texto de nossas liccões de Direito das Gentes o compendio desta materia do Conselheiro Autran (edicção de 1851), vamos expor, analysar, e desenvolver as doutrinas, que elle abiexpende, seguindo a mesma ordem dos seos capitulos e paragraphos. ${ }^{92}$

tanglements in Legal History: Conceptual Approaches, Global Per. Frankfurt am Main: Max Planck Institute for European Legal History, 2014, p. 411.

88 ZIMMERMANN, Eduardo, Translations of the "American Model" in Nineteenth Century Argentina: Constitutional Culture as a Global Legal Entanglement, in: DUVE, Thomas (Org.), Entanglements in Legal History: Conceptual Approaches, Global Per. Frankfurt am Main: Max Planck Institute for European Legal History, 2014, p. 391.

89 DRUMMOND, Preleções de Direito Internacional. p. 7285.

90 DRUMMOND, Preleções de Direito Internacional. p. 108, 180.

91 "O movel principal que nos determinou a esta publicação não foi, portanto, outro senão o desejo d ser útil á mocidade esperançosa, que cursa o $2 \square$ anno academico, procurando preaparal-a por meio de noções claras,e methodica, embora sucintamente expendidas, para o estudo accurado e completo desta sciencia tão deleitavel quanto util, e indispensavel, sobre tudo áquelles dentre a mesma a quem pode vir a ser no futuro confiado o iportante encargo de dirigir as relações exteriores de sua patria.”. SOUZA, Lições Elementares de Direito das Gentes. p. II.

92 SOUZA, Lições Elementares de Direito das Gentes. p. 1.
In fact, his book could be entitled Comments on Pedro Albuquerque's 'Elementos do Direito das Gentes', once it is exactly what João Souza did. The scheme is the same for the whole book: he mentions what Pedro Albuquerque wrote, then comments on it. In general, 'Lições de Direito das Gentes' is a setback in relation to Drummond's book - which, curiously, he is utterly silent about. Besides the fact of it being a commentary on a book written almost forty years earlier, João Silveira de Souza barely mentioned other authors; only referring to Klüber, ${ }^{93}$ Wheaton, ${ }^{94}$ Vattel..$^{95}$ The only, yet significative, unprecedent is a reference to the Argentinian jurist Carlos Calvo (1824-1906) ${ }^{96}$; not just because Calvo was the only contemporary author mentioned, but for being the first time that a South-American author was cited in a Brazilian textbook of international law. The works of Andrés Bello (1832, 1844, 1847), for instance, had been entirely ignored by the Brazilian jurists, whose eyes were facing overseas, rather than to their close neighbours. The attitude of the Brazilian jurists was in keeping with the policy of Brazilian Empire towards Latin-America; indeed, due to the divergence between political regimes - the convulsive and unstable Latin-American republics in contrast to the legitimate and stable monarchy - the Brazilian state identified itself more with Europe than to its neighbours. ${ }^{97}$

In addition, different from Antonio Drummond, João Silveira de Souza was not concerned about the nationalisation of the teaching of international law; in his book, it could not be found references to the Brazilian context or legislation, whilst the usual European events were still there to illustrate the cases.

At this point, it is possible to state that was a Klüber tradition in the Brazilian literature on international law in that period: all the three books published during the Brazilian Empire (1822-1889) - Elementos do Direito das

93 SOUZA, Lições Elementares de Direito das Gentes. p. 65, $82,95$.

94 SOUZA, Lições Elementares de Direito das Gentes. p. 35, 74, 84, 87, 94, 98, 115, 175, 203.

95 SOUZA, Lições Elementares de Direito das Gentes. p. 56, $121,127$.

96 SOUZA, Lições Elementares de Direito das Gentes. p. 200, 203.

97 SANTOS, Luís Cláudio Villafañe G., O Brasil entre a América e a Europa, São Paulo: UNESP, 2004; PREUSS, Ori, Bridging the Island. Brazilians' Views of Spanish America and Themselves, 1865-1912, Madrid, Frankfurt am Main: Iberoamericana, Vervuert, 2011. 
Gentes, by Pedro Autran da Matta Albuquerque (1851), Prelecções de Direito Internacional by Antonio Menezes Vasconcellos de Drummond (1867), and Lições de Direito das Gentes by João Silveira de Souza (1889) - had been, to some extent, inspired by the Droit des Gens Moderne de l'Europe, composed by Johann Ludwig Klüber.

Being disciples of Klüber, there is no point to ascertain the particular conceptions and notions on the international law given by each of these Brazilian jurists; ${ }^{98}$ they were very similar between them, and all of them resembles that one from the German author:

\begin{abstract}
On appelle gens ou nations libres les états indépendans, considérés dans leurs rapports mutuels comme personnes morales. L'ensemble de leus droits réciproques et parfaits, $d u$ droit des états entr'eux, forme le droit des gens ou droit des nations. Ce droit est naturel, en tant qu'il dérive de la nature méme des relations que subsistent entre les états, positif, lorsqu'il est fondé sur des conventions expressses ou tacites.9
\end{abstract}

Briefly, despite the natural stratum still being a transcendent foundation, the emphasis was put in the con-

98 The definition of international law given by Pedro Albuquerque in his Elementos do Direito das Gentes: "O Direito das gentes (direito internacional, ou direito publico externo) he o complexo de regras que a razão deduz como conformes á justiça, ou que se fundão em convenções expressas ou tácitas, e que servem de determinar o procedimeno das nações entre si. O direito das gentes, divde-se pois em direito das gentes natural, e positivo; e este em direito pacticio (tratados publicos), e consuetudinario (costumes com força obrigatoria).”. ALBUQUERQUE, Elementos do Direito das Gentes. p. 3. In Antonio Drummond's Preleções de Direito Internacional: "O direito internacional, direito das gentes ou nações, emfim o direito publico externo é o complexo dos direitos individuais e reciprocos entre as mesmas nações, ou aliás - dos dictames fundados na justiça, ou adduzidos das relações mutuas, e convenções expressas entre elas. $\mathrm{O}$ direito internacional dividide-se portanto em Direito das gentes natural e positivo. O primeiro, quando se deriva da propria natureza que subsistem entre os Estados, e o segundo, quando funda-se nas ditas convenções: este em direito pacticio (tratados publicos), e consuetudinario (costumes com força obrigatoria).”. DRUMMOND, Preleções de Direito Internacional, p. 9-10. Finally, in João Silveira de Souza's Lições de Direito das Gentes, after trasncribing Pedro Albuquerque comments: "Aquellas regras de justiça dadas pela razão, anteriores e superiores á vontade humana como normas universaes e invariaveis da conducta das nações entre si constitutem o Direito das gentes absoluto; e as que resultão das convenç eos ou tratados que estas celebrão para melhor e de modo positivo estabelecer entre si certos direitos e obrigações que aquelle não impõe immediatamente, constituem o Direito das gentes positivo ou convencional; no qual se comprehende, como nos observa o compendio, o Direito das Gentes, consuetudinario, consistente nas regras geralmente admittidas pelo uso ou consentimento de todas as nações, e que, portanto, a nenhum é lícito violar seo arbitrio, em prejuizo das mais.”. SOUZA, Lições Elementares de Direito das Gentes. p. 4.

99 KLÜBER, Johann Ludwig, Droit des gens moderne de l'Europe, Sttugart: J.G. Cotta, 1819. p. 11-12. ventions and treaties agreed by the states in their relations. Thus, when Klüber enlisted the sources of that legal system, the very first was the conventions, express or tacit, ${ }^{100}$ followed by the analogy, ${ }^{101}$ and only in the third place the droit des gens naturel, which being subsidiary, it should only be applied if the droit positif was insufficient. ${ }^{102}$

That conception that had been taught in the Brazilian law faculties for almost the whole nineteenth century, either through these three textbooks written by Brazilian professors, or from the writings of Klüber and Martens, directly. Only by the beginning of twentieth-century other doctrines of international law started to emerge in the Brazilian context, with works by Sá Vianna, Clovis Bevilaqua and Lafayette Pereira.

\section{Conclusion}

It is quite remarkable that the very first book of international law published in Brazil and written by a Brazilian is a condensed translation of a European author. Although it might not be a case of plagiarism, as explained - mainly because Klüber was well-known in Brazil at that time -, it is certainly a case of appropriation of foreign doctrine. Appropriation yet does not mean reproduction. Pedro Albuquerque did manipulate the book, or, to use an expression from Lydia Liu, he negotiated with the text: omitting some topics, suppressing particular references, or by explaining the rules with familiar experiences. This operation, far from being a passive imitation, promoted a sort of mediation between that exogenous body of norms and the Brazilian context. Mediation that had been favoured by the permanently present sentiment of cultural inheritance from Europe, turning easier the assimilation of international law among the Brazilian jurists.

His subsequent colleagues at the Faculty of Recife, Vasconcelos de Drummond and Silveira de Souza, continued the project. Preserving Klüber's Droit des Gens as

100 KLÜBER, Johann Ludwig, Droit des gens moderne de l'Europe, Sttugart: J.G. Cotta, 1819. p. 15-16.

101 KLÜBER, Johann Ludwig, Droit des gens moderne de l'Europe, Sttugart: J.G. Cotta, 1819. p. 17-18.

102 "En troisième lieu vient le Droit des gens naturel. On doit y avoir recours toutes les fois que le droit positif est insuffisant.". KLÜBER, Johann Ludwig, Droit des gens moderne de l'Europe, Sttugart: J.G. Cotta, 1819. p. 18. 
the main reference, they propelled the adaptation of European international law in a peripheric State by contextualizing the rules and illustrating with treaties signed by Brazil. On the whole, all books written by Brazilian authors throughout the nineteenth-century took inspiration from the German jurist Johann Ludwig Klüber even the collection of treaties prepared by Antonio Pereira Pinto can be attributed to that tradition that used to make this kind of literature.

By the mid-nineteenth century, when Pedro Autran published Elementos de Direito das Gentes, the tradition founded by Klüber and Martens was considered old-fashioned in Europe. It is quite symbolical that specially the author that particularized the international law, applying it only to European countries happened to be used as a paradigm for almost the entire century in Brazil. In other words, the Brazilian jurists operated the universalization, or at least the expansion of the international law to Brazil, based on a particularistic-Europeanized understanding of that same law.

The emphasis on appropriation and adaptation in the present narrative helps to reveal - the often neglected, but actually decisive - role of peripherical jurists in the process of diffusion of international law, and as a consequence, in the universalization of it.

\section{References}

ALBUQUERQUE, Pedro Autran da Matta. Elementos do Direito das Gentes. Recife: Typographia União, 1851.

ANGHIE, Antony. TWAIL: Past and Future. International Community Law Review, v. 10, n. 4, p. 479481, 2008.

ANTONY ANGHIE. Imperialism, Sovereignty and the Making of International Law. Cambridge: Cambridge University Press, 2004.

BENEDUCE, Pasquale. Il corpo eloquente. Identificazione del giurista nell'Italia liberale. Bologna: il Mulino, 1996.

BETHELL, Leslie. The abolition of the Brazilian slave trade: Britain, Brazil and the slave trade question (1807-1869). Cambridge: Cambridge University Press, 1970.
BEVILAQUA, Clovis. História da Faculdade de Direito do Recife. Brasília: Instituto Nacional do Livro, Conselho Federal de Cultura, 1977.

BLAKE, Sacramento. Diccionario Bibliographico Brazileiro. Vol. 1-7. Rio de Janeiro: Typographia Nacional, 1883.

CARVALHO, José Murilo De. História intelectual no Brasil: a retórica como chave de leitura. Topoi, v. 2, n. 1, p. 123-152, 2000.

CERVO, Amado Luiz; BUENO, Clodoaldo. História da política exterior do Brasil. 5. ed. Brasília: Editora Universidade de Brasília, 2015.

CHIMNI, Bhupinder S. Abordagens Terceiro-Mundistas para o Direito Internacional: um manifesto. Revista de Direito Internacional, v. 15, n. 1, 2018.

DRUMMOND, Antônio de Vasconcellos Menezes de. Preleções de Direito Internacional. Recife: Typographia do Correio do Recife, 1867.

FIOCCHI MALASPINA, Elisabetta. L'eterno ritorno del Droit des gens di Emer de Vattel (scc. XVIIIXIX). Frankfurt am Main: Max Planck Institute for European Legal History, 2017.

FIOCCHI MALASPINA, Elisabetta; KELLER-KEMMERER, Nina. International Law and Translation in the 19th century. Rechtsgeschichte, v. 22, p. 214-226, 2014.

FOLJANTY, Lena. Translators: Mediators of Legal Transfers. Rechtsgeschichte, v. 24, p. 120-121, 2016.

GALINDO, George Rodrigo Bandeira. Martti Koskenniemi and the historiographical turn in international law. European Journal of International Law, v. 16, n. 3, p. 539-559, 2005.

GALINDO, George Rodrigo Bandeira. Para que serve a história do direito internacional? Revista de Direito Internacional, v. 12, n. 1, p. 339-354, 2015.

HALLEWELL, Laurence. O Livro no Brasil: Sua História. 2. ed. São Paulo: Editora da Universidade de São Paulo, 2005.

HOLANDA, Sérgio Buarque de. Raízes Do Brasil. São Paulo: Companhia das Letras, 1995.

JACOBINI, H.B. A Study of the Philosophy of International Law as Seen in Works of Latin American Writers. The Hague: Martinus Nijhoff, 1954. 
KEMME, Clara. The History of European International Law from a Global Perspective: Entanglements in Eighteen and Nineteenth Century India. In: DUVE, Thomas (Org.). Entanglements in Legal History: Conceptual Approaches. Frankfurt am Main: Max Placnk Institute for European Legal History, 2014, p. $489-542$.

KLÜBER, Johann Ludwig. Droit des gens moderne de l'Europe. Sttugart: J.G. Cotta, 1819.

KOHL, G. Zeiller, Franz von (1751-1828). In: STOLLEIS, Michael (Org.). Juristen. Ein biographisches Lexikon. Von der Antike bis zum 20. Jahrhundert. München: Beck, 1995, p. 668-670.

KOSKENNIEMI, Martti. Into Positivism: Georg Friedrich von Martens (1756-1821) and Modern International Law. Constellations: An International Journal of Critical \& Democratic Theory, v. 15, n. 2, p. 189207, 2008.

KOSKENNIEMI, Martti. The Gentle Civilizer of Nations. The Rise and Fall of International Law. 1870-1960. Cambridge: Cambridge University Press, 2004.

LIU, Lydia H. The Clash of Empires. The Invention of China Modern World Making. Cambridge: Harvard University Press, 2004.

LORCA, Arnulf Becker. Alejandro Alvarez Situated: Subaltern Modernities and Modernisms that Subvert. [s.l.: s.n.], 2006.

LORCA, Arnulf Becker. Eurocentrism in the history of international law. In: PETERS, Anne; FASSBENDER, Bardo (Orgs.). The Oxford Hadbookf of the History of International Law. Oxford: Oxford University Press, 2012, p. 1034-1057.

LORCA, Arnulf Becker. International Law in Latin America or Latin American International Law? Rise, Fall, and Retrieval of a Tradition of Legal Thinking and Political Imagination. Harvard International Law Journal, v. 47, n. 1, p. 283-305, 2006.

LORCA, Arnulf Becker. Mestizo International Law. A Global Intellectual History 1842-1933. Cambridge: Cambridge University Press, 2014.

MERRY, Sally. What is Legal Culture? An anthropological Perspective. Journal of Comparative Law, v. 5, n. 2, p. 40-58, 2012.
NABUCO, Joaquim. Minha formação (1893). Rio de Janeiro: Nova Fronteira, 2015.

NUZZO, Luigi. Origini di una Scienza. Diritto internazionale e colonialismo nel XIX secolo. Frankfurt am Main: Vittorio Klostermann, 2012.

OBREGÓN, Liliana. Carlos Calvo y la profesionalización del Derecho internacional. Revista Latinoamericana de Derecho Internacional, p. 1-23, 2016.

OBREGÓN, Liliana. Construyendo la región americana: Andrés Bello y el Derecho Internacional. In: CHOPO, Yolanda Gamarra (Org.). La idea de América en el pensamiento ius internacionalista del siglo XXI. Zaragoza: Institución Fernando El Católico, 2010, p. $65-86$.

OBREGÓN, Liliana. Construyendo la Región Americana: Andrés Bello y el Derecho Internacional. Revista de Derecho Público de la Universidad de Los Andes, v. 24, p. 1-22, 2010.

OBREGÓN, Liliana. Creole Consciousness and International Law in Nineteenth Century Latin America. In: ORFORD, Anne (Org.). International Law and Its Others. Cambridge: Cambridge University Press, 2006, p. 247-264.

OKAFOR, Obiora Chinedu. Critical Third World Approaches to International Law (TWAIL): Theory, Methodology, or Both? International Community Law Review, v. 10, n. 4, p. 371-378, 2008.

PETIT, Carlos. Discurso sobre el discurso. Oralidad y escritura en la cultura jurídica de la España liberal. Madrid: Universidad Carlos III de Madrid, 2014.

PINTO, Antonio Pereira. Apontamentos para o Direito Internacional. Rio de Janeiro: F. L. Pinto \& Cia, 1864.

PREUSS, Ori. Bridging the Island. Brazilians' Views of Spanish America and Themselves, 18651912. Madrid, Frankfurt am Main: Iberoamericana, Vervuert, 2011.

SAMPAIO DE MORAES GODOY, Arnaldo. The reception of European ideas in Latin America: the issue of the German sources in Tobias Barreto, a prominent nineteenth century Brazilian legal scholar. Revista de Direito Internacional, v. 13, n. 1, p. 399-404, 2016.

SANTOS, Pedro Afonso Cristovão dos. Compilação e plágio: Abreu Lima e Melo Morais lidos no Instituto 
Histórico e Geográfico Brasileiro. Revista da História da Historiografia, v. 13, p. 45-62, 2013.

SANTOS, Luís Cláudio Villafañe G. O Brasil entre a América e a Europa. São Paulo: UNESP, 2004.

SCARFI, Juan Pablo. E1 imperio de la ley. James Brown Scott y la construcción de un orden jurídico interamericano. Buenos Aires: Fondo de Cultura Económica, 2014.

SCARFI, Juan Pablo. The Hidden History of International Law in the Americas: Empire and Legal Networks. Oxford: Oxford University Press, 2017.

SOUZA, João Silveira de. Lições Elementares de Direito das Gentes. Recife: Typographia Economica, 1889.

STEIGER, H. From the International Law of Christianity to the International Law of the World Citizen. Journal of the History of International Law, v. 3, n. 2, p. 180-193, 2001.
VEC, Miloš. Universalization, Particularization, and Discrimination . European Perspectives on a Cultural History of 19th century International Law. InterDisciplines, v. 2, p. 79-102, 2012.

WIJFFELS, Alain. Early-modern scholarship on international law. In: ORAKHELASHVILI, Alexander (Org.). Research Handbook on the Theory and History of International Law. Chelthenham, Nothampton: Edward Elgar Publishing, 2011, p. 23-60.

ZIMMERMANN, Eduardo. Translations of the "American Model" in Nineteenth Century Argentina: Constitutional Culture as a Global Legal Entanglement. In: DUVE, Thomas (Org.). Entanglements in Legal History: Conceptual Approaches. Global Per. Frankfurt am Main: Max Planck Institute for European Legal History, 2014, p. 385-426. 
Para publicar na Revista de Direito Internacional, acesse o endereço eletrônico www.rdi.uniceub.br ou www.brazilianjournal.org.

Observe as normas de publicação, para facilitar e agilizar o trabalho de edição. 